\title{
The Performance of Psychology Professionals in CRAS in the Countryside of Paraíba
}

\author{
Orlando Júnior Viana Macêdo ${ }^{1,2, \text { * }}$ \\ Orcid.org/0000-0001-5416-4930 \\ Clarissa Maria Paulino Duarte Lima ${ }^{2}$ \\ Orcid.org/0000-0002-3474-0803 \\ Francisco Henrique Sousa de Brito ${ }^{2}$ \\ Orcid.org/0000-0003-4200-2517 \\ Josefa Nandara Pereira de Souza ${ }^{2}$ \\ Orcid.org/0000-0003-2182-9099 \\ Noélia Kally Marinho de Sousa ${ }^{2}$ \\ Orcid.org/0000-0002-2206-9477 \\ Samara Pereira De Sousa ${ }^{2}$ \\ Orcid.org/0000-0002-9738-4180 \\ Stefania Germano Dias ${ }^{2}$ \\ Orcid.org/0000-0003-2910-1174
}

${ }^{1}$ Faculdade Juazeiro do Norte, Juazeiro do Norte, CE, Brasil

${ }^{2}$ Faculdade Santa Maria, Cajazeiras, PB, Brasil

\begin{abstract}
This study aims to analyze the performance of Psychology professionals in the Basic Social Protection of the Social Assistance Public Policies. To meet this objective, Cultural-Historical Psychology was used as theoretical support. Eight Psychology professionals who worked at the Reference Center for Social Assistance (CRAS) in the countryside of Paraíba, northeast of Brazil, were interviewed. Semistructured interviews were made, individually. Content analysis was used to analyze data. Empirical data revealed: Academic background oriented to individualizing clinical practice; Limited theoretical and methodological support for the professionals' performance; Demands arising from social vulnerability conditions, violation of rights and mental health; Predominance of psychosocial performance; and several limitations that make the work of the Psychology professional difficult. The conclusion is that both, improvements in the academic background of the Psychology professionals and a more engaged work of professionals regarding the fight for improvements in consolidating a system of rights guarantee, are needed.
\end{abstract}

Keywords: Psychology, Psychologist's performance, CRAS, Cultural-Historical Psychology.

* Mailing address: Rua Rodrião Ferreira de Sousa, 21, bairro Tiradentes, Juazeiro do Norte, CE, Brazil. Phone: (88) 9 8807-0618. E-mail: orlandojrvm@yahoo.com.br 


\section{Atuação dos Profissionais de Psicologia nos CRAS do Interior da Paraíba}

\section{Resumo}

Objetiva-se no presente estudo analisar a atuação dos profissionais de Psicologia na Proteção Social Básica das Políticas Públicas de Assistência Social. Para dar conta de tal objetivo buscou-se suporte teórico na Psicologia Histórico-Cultural. Participaram do estudo oito profissionais de Psicologia que atuavam no Centro de Referência da Assistência Social (CRAS) do interior da Paraíba, Nordeste do Brasil. Recorreu-se a entrevistas semiestruturadas, realizadas individualmente. Para analisar os dados recorreu-se à análise de conteúdo. Dados empíricos revelaram formação acadêmica voltada para a atuação clínica individualizante, limitado suporte teórico-metodológico para atuação dos profissionais, demandas decorrentes da condição de vulnerabilidade social, violação de direitos, mas também de saúde mental e predomínio de atuação psicossocial e diversas limitações que dificultam a realização do trabalho do profissional de Psicologia. Conclui-se pela necessidade tanto de avanços na formação acadêmica dos profissionais de Psicologia, quanto de atuação engajada na luta por avanços na consolidação de um sistema de garantia de direitos.

Palavras-chave: Psicologia, atuação do psicólogo, CRAS, Psicologia Histórico-Cultural.

\section{La Actuación de los Profesionales de la Psicología en los CRAS en Pueblos de Paraíba}

\section{Resumen}

Este estudio tiene como objetivo analizar la actuación de los profesionales de Psicología en la Protección Social Básica de las Políticas Públicas de Asistencia Social. Para ello, fue utilizado como soporte teórico la Psicología Histórico-Cultural. En el estudio participaron ocho profesionales de Psicología que actuaban en los Centros de Referencia de Asistencia Social - CRAS en pueblos del estado de Paraíba, noreste de Brasil. Entrevistas semiestructuradas fueran utilizadas, hechas individualmente. Para analizar los datos, se utilizó el análisis de contenido. Los datos empíricos revelaron que: los profesionales cuentan con una formación académica direccionada hacía la actuación clínica individualizada; tienen un respaldo teórico y metodológico muy limitado para sus actuaciones como profesionales; las demandas son decurrentes de la condición de vulnerabilidad social, violación de los derechos y de la salud mental; predominó la actuación psicosocial; además, emergieran diversas limitaciones que dificultaban la realización de su trabajo como profesional de Psicología. Se concluye entonces que hay una gran necesidad de avances en la formación académica de los profesionales de Psicología, a ello se añade una actuación profesional más comprometida en la lucha por los avances en la consolidación de un sistema de garantía de derechos.

Palabras clave: Psicología, actuación del psicólogo, CRAS, Psicología Histórico-Cultural.

The Basic Social Protection of the Public Social Welfare Policy aims to prevent any violation of rights arising from a situation of poverty, a lack of income or access to public services, and from various types of discrimination (Ministério do Desenvolvimento Social e Combate à Fome, 2009). The current configuration of the Social Welfare Policy as a public policy that is divided into levels of complexity (Basic Social Protection and Medium and Highly Complex Special Social Protection) was the result of the progress made in legal frameworks that sought to overcome the historical welfarism and patronage that have been present throughout the history of welfare policies in Brazil. The Constitution of 1988, the Social Welfare System Organic Law 
(LOAS), the National Social Welfare Policy (PNAS) and the consolidation of the Single Social Welfare System (SUAS) stand out as an important legal framework in this process.

As Alberto, Freire, Leite, and Gouveia (2014) point out, the 1988 Constitution integrated social welfare into a broader principle of social protection, which identified with social security. This represented a significant gain, since the social welfare policy had been conceived as a welfarist action of a nature that was either philanthropic, welfarist or as a favor to the poor. The Constitution instituted the continuous provision benefit (BPC) and established the rules of institutional organization, by which decentralization of the performance of actions was established, along with the federal sphere's responsibility for coordinating and defining the general rules (Constituição da República Federativa do Brasil, 1988). It also guaranteed social participation in formulating and controlling this policy (1988).

The LOAS (Law No. 8,742, 1993), which was enacted in 1993, established social welfare as being a non-contributory right of all and the duty of the State. It defined its objectives as being: protection for the family, maternity, childhood, adolescence and old age; protection for needy children and adolescents; the promotion of integration into the labor market; assistance for the disabled and their integration into community life; and the guarantee of a monthly minimum wage as a benefit for the disabled and the elderly, provided they can prove they do not have the means to maintain themselves, or be provided for by their family (Article 2). Among other things, the LOAS has as its principles: the supremacy of social needs; rights for all; respect for the dignity and autonomy of citizens; the primacy of state responsibility; and the participation of organized civil society (Ministério do Desenvolvimento Social, 2004).

As Cruz and Guareshi (2010) point out, with the approval of the National Social Welfare Policy (PNAS) in 2004, an attempt was made to consolidate the principles, guidelines, objectives and actions of social welfare. This policy was initially based on the logic of territoriality and the centrality of the family as the social nucleus, following guidelines established by the PNAS. The option was given of intervention being guided by the identification of "concrete problems, potentialities and solutions, all starting from a territorial perspective" (Ministério do Desenvolvimento Social, 2004, p. 37) and by the "centrality of the family when designing and implementing benefits, services, programs and projects" ( $p$. 33), all of which go to make up a set of services and programs based on the organization and hierarchization of network actions that respect the complexity levels of the system and the criterion of universal access. An attempt was thus made to enable a dynamic analysis to be carried out of the reality of Brazilian municipalities and to provide a service for those in a situation of risk and social vulnerability (Ministério do Desenvolvimento Social, 2004).

In 2005, with consolidation of the SUAS, the PNAS was reordered to make its actions more effective, with actions in social welfare at the national level being unified. As Alberto et al. (2014) stress, the SUAS materializes and gives form to the LOAS as it puts into operation rights that are guaranteed by the Constitution as being the mechanisms of social protection. As Romagnoli (2015) points out, the basis of the PNAS is strengthening the capacity of individuals and families to face up to their vulnerability, with a view to protecting them from social risk situations. This legal framework presents a proposal that is different from the historical tradition of social welfare policies in Brazil, which are marked by charity, philanthropy and goodwill towards those who are deserving and in need, thus mobilizing help for the poor and poverty-stricken (Alberto et al., 2014; Cruz \& Guareshi, 2010). Implementation of this new welfare model, however, has been hampered by the challenges imposed by the international scenario and the domestic situation of the Brazilian economy, involving a combination of low growth rates and high rates of inflation, and that continues to reproduce the logic of a neo-liberal ideology, which mainly penalizes the subaltern classes (Gonçalves, 2010).

It is also worth pointing out that, as Ribeiro and Guzzo (2014), Romagnoli (2015) and Sicari, 
Oliveira, and Pereira (2015) draw attention to, although the current model is democratic and productive on paper, it is the professionals who work on a day-to-day basis that make public policies viable, or not. These authors provide evidence of the contradictions that exist between what is proposed in the legislation and what is actually experienced by professionals. Ribeiro, Paiva, Seixas, and Oliveira (2014) add that legally established social conquests have been operationalized slowly, gradually and in a dissonant way since their original political proposal. This is because of the limitations of the policies themselves, which are the result of party political interests within the current context of any increase in neoliberalism and the consequent dismantling of social policies and rights, and limitations in the academic formation of the professionals who are responsible for making such policies feasible (Macêdo, 2014).

In the light of the above, in recent years we have seen the development of a wide process of debates, research and production about the action of psychology within the context of public social welfare policies. This has led to a significant change in our understanding of the responsibilities and attributes of the psychology professionals who work with public social welfare policies (Alberto et al., 2014; Freire \& Alberto; 2013, Florentino, 2014; Hillesheim \& Cruz, 2012; Macêdo, 2014; Macêdo, Alberto, \& Pessoa, 2015; Moreira \& Paiva, 2015; Motta \& Scarparo, 2013; Ribeiro \& Guzzo, 2014; Romagnoli, 2015, 2016; Senra \& Guzzo, 2012; Siqueira $\&$ Lino, 2013, and others). From these studies it can be perceived that, within the context of public social welfare policies and so as to contribute to the development of the protagonism and autonomy of the users, psychology professionals should distance themselves from welfarist or repressive practices that blame individuals and their families for the situation in which they find themselves.

With regard to specific action within the scope of the basic social protection of the public social welfare policy, in a study carried out in Porto Alegre in the State of Rio Grande do Sul and based on the Social Representations Theory,
Pereira and Guareshi (2016) found that psychology actions are operationalized both in the sense of individualizing, blaming, adjusting and normatizing users and by way of a relational perspective, questioning their own conceptions and actions, and seeing in users the possibilities for transformational, micropolitical relationships and partnerships. In an analysis of social practices and psychology-based knowledge in the Social Welfare Reference Center (CRAS), which had recourse to Foucault's ideas as its theoretical contribution, Oliveira and Heckert (2013) also found similar results and came to the conclusion that the CRAS can function as a control device, and also as a space for deviations in the field of social welfare policies.

Based on a supervised internship experience in the State of Minas Gerais, Sicari et al. (2015) analyzed the discourse of psychology professionals with regard to poverty and identified processes that blame users; these professionals attribute to such individuals an irresponsibility or demotivation as far as changing their situation is concerned, and they deny the extent and social dimension of the poverty phenomenon. Silva, Brustolin, and Pessini (2011) also drew attention to the implication in the psychological practices carried out in the CRAS, which, when they are based on welfarist practices, lead to users being unaware that they are citizens who have rights and that compromise their understanding of social vulnerability.

When Flor and Goto (2015) studied the context of the CRAS in Uberlândia in the State of Minas Gerais, they identified that limitations in the academic formation in psychology, a lack of systematization in psychological practice and a real appropriation of policy knowledge have led to an absence of objective references and practices for the work of psychology professionals. Macêdo, Alberto, Santos, Sousa, and Oliveira (2015) studied psychology professionals in the State of Ceará and also identified limits in their academic formation, which provides more support for individualizing clinical work. They drew attention to the limited reach of such work and propose that professionals ought to have recourse to versions of psychology that are more 
politicized and committed to realizing the rights of individuals living in a situation of social vulnerability, through work that is based on the real demands of those at whom the action is aimed.

When analyzing the work of psychology professionals in the CRAS in the metropolitan region of Natal, in the State of Rio Grande do Norte, Oliveira, Dantas, Solon, and Amorin (2011) identified different actions in the traditional practices of psychologists, but draw attention to the fact that the traditional clinic once more emerges as an area of relative comfort for the work of these professionals. With regard to the context of the interior of the State of Rio Grande do Norte, Oliveira et al. (2014) found that, although it has some specificities, the professional practice of psychologists in the CRAS did not vary structurally when compared with that performed in the Natal Greater Metropolitan region.

It is evident that the context of the basic social protection of public social welfare policies is still not comfortable for psychology work; also because of the predominance of actions based on individual perspectives and the decontextualized analyses of the social reality in which the individuals who are being helped by the policy find themselves. This statement is justified because of the still significant challenges that psychology faces in the context of public social welfare policies, since the entry of psychology professionals into social welfare reference centers has exposed them to the demands of the subaltern classes, by way of the work they do, the focus of which should be on the living conditions of people, on structural poverty (Oliveira et al., 2014). The history of psychology shows that in many instances this science and profession were used for control, segmentation, and differentiation, as ways of contributing to the maintenance and increase in the profit necessary for the reproduction of capital (Yamamoto \& Oliveira, 2010), thus serving the interests of the elite and not the subaltern classes.

The fact that psychology does not yet have a consolidated ethical-political project and the fact that the PNAS is still not a clearly consolidated policy, which is evidenced by the gap that exists between the design of the SUAS and its operationalization, are factors that go to make up the context of public social welfare policies. In addition to these aspects, this article is justified because there are few studies on the reality of the interior of the State of Paraíba, and because of the contradictory results that sometimes point to the actions of psychology as being predominantly based on an individualizing clinical model, and sometimes on psycho-social perspectives.

It is not possible to think about the action of psychology within the scope of public welfare policies while disregarding the current context of economic, political and social crisis, which constitutes a scenario with multiple relationships. As a result of these relationships, however, there are, on the one hand, groups of people committed to human rights and social struggle based on a recognition of explicit social inequalities; and on the other hand, segments that are committed to maintaining these inequalities, with the unequal distribution of income and the extermination of human rights. The question this raises, therefore, is: what interests has psychology served in the way it has been acting in the CRAS given the sequels resulting from the expressions of social issues?

Social issues are understood to be the political, social and economic problems posed by the emergence of the working class in the process of constituting the capitalist society (Yamamoto \& Oliveira, 2010). It is believed that the CRAS teams - basic social protection reference units should act in harmony with the PNAS guidelines and objectives in an interdisciplinary way that is integrated with the local context, thus identifying and boosting psycho-social resources (Conselho Federal de Psicologia [CFP], 2007, 2011, 2013). Interventions should occur at the individual, family, group and community levels, by way of contextualized and collective practices.

In carrying out this study, theoretical support was sought in the cultural-historical psychology of Vygotski (1934/2007, 1934/2009). The author in question starts from the understanding that subjectivity cannot be analyzed by disregarding objective reality, since the concrete reality in which the subject is found and different 
historical, political and cultural conditions produce transformations not only in their representation of the reality that surrounds them, but also in their innermost being.

With regard to this external/internal social/ individual relationship, Vygotsky (1934/2007) considers that the internalization of cultural forms of behavior involves the reconstruction of psychological activity, which has operations with signs as its basis. We establish relationships with others when we play a role vis-à-vis another person, while this other person plays a role vis-àvis us. It is worth emphasizing that human social relationships are historically constituted by way of social struggles and power relationships that are culturally inseparable.

In view of the above, this article aims to analyze the work of psychology professionals in the basic social protection of public social welfare policies. To achieve this objective, research was carried out involving eight psychology professionals who work in the Welfare Reference Centers (CRAS) of six municipalities in the interior of Paraíba, a state in the Northeast region of Brazil.

\section{Method}

\section{Context and Participants}

The psychology professionals who took part in this study work in the CRASs in six municipalities in Paraíba. These municipalities are neighboring towns of Cajazeiras and $490 \mathrm{~km}$, on average, from the state capital of Paraíba, João Pessoa.

The research involved a total of eight participants, seven of whom were female and one was male. The criterion used for choosing those participating in the study was convenience, while the number of psychology professionals was defined using the saturation criterion (Fontanella, Ricas, \& Turato, 2008). The participants' ages ranged from 24 to 55 years old, with a mean age of 37.3 years. Only one of the eight participants was male. It was decided not to reveal the municipalities that were part of the study as a way of guaranteeing the anonymity of the participants, since in some of those municipalities adjoining
Cajazeiras there is only one psychology professional working in the CRAS.

\section{Instrument}

Semi-structured, individual interviews were used. In addition to biological, social and demographic data, the interviews included questions relating to the following topics: the orientation of the academic formation, the theoreticalmethodological reference they use to guide their professional activities, the demands they face in their professional work, what they do in a typical working week and the working conditions in the CRAS. The questions used in the semi-structured interviews were prepared by the researchers themselves.

\section{Collection Procedure}

After authorization was received from the Social Welfare Departments in the municipalities in the interior of Paraíba and from the CRAS coordinators, interviews were scheduled that took place in the workplace of the psychology professionals. The interview schedule took into account the availability of the professionals and the researchers, who were previously trained to conduct such interviews, which lasted 35 minutes, on average. They were carried out following an explanation of the purpose of the study, the signing of the Term of Free and Informed Consent, and authorization being granted for recording. All those professionals who were invited agreed to take part in the study.

\section{Data Analysis Procedures}

Having recorded the interviews, the interviewees' words were faithfully transcribed and analyzed by way of content analysis, more specifically using the thematic analysis technique (Bardin, 2009). A cursory interpretation was carried out, therefore, of all the transcribed and printed material in order to have an idea of the content as a whole of what the individuals had said. This material was subsequently tabulated, a process which involved an aggregation of similar themes.

Based on the following themes: Requests they face; What they do in a typical working 
week, and Working conditions, the raw text data were codified and transformed in order to represent the content, with the analyst clarifying the characteristics of the text. The categories that represent the meaning nuclei emerged from the codification. A validation technique was chosen that involved two judges, both of whom had been previously trained for this purpose. The categories will now be presented and discussed, following the order from the most representative to the least representative.

\section{Ethical Procedures}

Prior to the start of data collection, this project was registered on the Brazil Platform and sent to the Research Ethics Committee (CEP) of Santa Maria College (FSM), which approved it under opinion number 1,085,249. All the research was conducted in accordance with Resolution 466/12 of the National Health Council / Ministry of Health (2012).

\section{Results and Discussion}

\section{Profile of the Psychology Professionals}

The age of the study participants ranged from 24 to 55 years old, the mean age being 37.3 and the standard deviation 11.71. Only one of the eight participants was male. There is still a notable predominance of women working in the welfare area, a fact that was also identified by Macedo et al. (2011). As Russo, Cisne, and Bretas (2008) draw attention to, this majority presence of women in welfare has been following the policy in question since it started. They add that, although under another guise, the idea remains that woman's role is to harmonize the social conflicts caused by poverty.

Those interviewed graduated between 3 and 29 years ago, the average being 9.6 years, although professionals who finished university 4 years ago predominated. The time they had worked in the CRAS varied from less than six months to ten years, the average being three and a half years. Four of the eight participants had undergone a normal hiring process and four had entered by way of a civil service entry exam.
Five of the participants worked only with the social welfare policy, while two of them revealed that they had another activity in the Psychosocial Care Center (CAPS) and one in the Family Health Support Center (NASF). The study participants divide their working time between the CRAS and other contexts, which according to Macedo (2007) is due to the need to supplement their incomes. This can compromise the quality of their work, in view of the limited time available for planning and intervention difficulties in partnership with other professionals who go to make up the CRAS team.

Most of the professionals interviewed in the research revealed that their academic background involved curricular internships that focused on clinical practice, by way of an individualizing model. A few of them also referred to other academic background possibilities, reporting that during their undergraduate studies they had been involved in internship programs in hospital, mental health, school and justice contexts.

This aspect points to the professionals having an academic background that can hinder their work with public social welfare policies, since the work done in the CRAS demands contextualized and collective practices. These findings with regard to the direction of their academic background in psychology corroborate the results of other studies (Freire \& Alberto, 2013; Macêdo, Alberto, Santos et al., 2015; Motta \& Scarparo, 2013). The following statement is representative of this reality:

Not to mention that we didn't discuss anything at the time. There was a discipline in which the teacher worked with topics relating to services that involve protection against violence, which instead of being the CREAS, was formerly the old Sentinela program. It was the only, very partial contact we had. I had no idea what it was [referring to the CRAS]. (Interviewee 1, a 28-year old, female, who graduated six years ago)

In this sense the psychology professionals working with social welfare in the interior of Paraíba had access to an academic formation based on a model that has historically gone into 
making up the scope of this profession, which makes it difficult for them to act from a psychosocial perspective that promotes the autonomy and protagonism of CRAS users. This can be partly explained by the fact that some of the participants of this study were not included in the psychology Course Teaching Project (PPC), which resulted from the National Curricular Guidelines (DCNs) and that were approved in 2004 (Conselho Nacional de Educação). As Seixas, Coelho-Lima, Fernandes, Andrade, and Yamamoto (2016) emphasize, discussions about an academic formation in psychology that focuses on social policies have had a guaranteed place in the PPCs, despite little emphasis being given to the public social welfare policy.

The words of the psychology professionals also revealed that they use the following references to guide their practice in the CRAS: Technical References of the CFP / Legal frameworks of the MDS; the Cognitive-Behavioral Theory, the Person-Centered Approach and social psychology. Two of the interviewees said they use no theoretical framework whatsoever.

It is worth pointing out that, although the questioning was about the theoretical-methodological reference, most comments dealt with technical references, such as the reference guides prepared by the Reference Center in Psychology and Public Policy (CFP, 2007, 2013) and the legal frameworks of the SUAS. This reinforces the idea regarding the limitations of the academic formation of these professionals for working within the scope of the basic social protection of the public social welfare policy. The empirical data provide evidence of the difficulty that psychology professionals have when it comes to appropriating the theoretical reference points of psychology that enable demands to be analyzed and interventions planned.

This aspect may reveal a training model that is still technical, which teaches what to do and how to do it, but without providing any clarity as to the need to analyze the real demands, to plan interventions, and to reflect on the scope of the training and what interests it serves. Macêdo, Alberto, and Pessoa (2015) draw attention to the importance of psychology professionals having access, throughout their undergraduate years, to psychology models that go beyond individual and decontextualized perspectives of analysis and intervention with regard to reality. Working in the CRAS requires actions that deal with the living conditions of the people, their structural poverty (Oliveira et al., 2014), based on the real demands of the individuals for whom the action is intended (Macêdo, Alberto, Santos et al., 2015).

Thinking of a theoretical reference point to be used in the CRAS is thinking about work that strengthens social and community coexistence in the place in which the families that are helped by such a policy live. This requires getting as close as possible to the daily reality of CRAS users, since this is where the risks and vulnerabilities are constituted. This being so, the proposal must be based on the ethical dimension of providing individuals from the subaltern classes with visibility. This reality demands interdisciplinary, intersectoral and family-centered action (Florentino, 2014). An attempt must be made to understand the individual and the family based on their objective reality, in other words, to understand the recurrences and singularities of a wide variety of micro-social arrangements, not just reacting to the impositions of society, but participating in its creation and the creation of daily life, turning to working directly with the groups, thus having a participatory methodology and seeking to understand the individual and awaken them to their social reality (Ximenes, De Paula, \& Barros, 2009). For, as Vygotsky (1934/2007) points out, individuals constitute their subjectivity based on their interactions with objective reality.

\section{Demands}

With regard to the theme, Demands that professionals face in the CRAS, the following categories emerged from the reports of the professionals: social vulnerability, rights' violation and mental health. The 'Social vulnerability' category denotes the reality of CRAS users that is marked by low income, the absence of work or its precarious nature, and precarious access to basic living conditions. 
The 'Rights' violation' category, which emerged from the words of the psychology professionals, revealed that these professionals are faced with the demands of children, women and elderly people whose rights have been violated. The words of these professionals also pointed to demands that fall outside the scope of the public social welfare policy, which was represented by way of the 'Mental health' category.

The 'Mental health' category reveals that both from spontaneous demands and referrals from education bodies and the courts, it is expected that CRAS psychology professionals will reproduce a model based on the precepts of the individualizing clinic, providing psychotherapeutic monitoring or producing reports and psychological assessments.

Because the CRAS facility deals with the basic social protection of the public social welfare policy, it must act from the perspective of preventing any violation of the rights of those individuals who live in a situation of social vulnerability. As Romagnoli (2015) points out, this refers to unfavorable situations and the objective dimensions of social exclusion. He adds that these are situations by way of which individuals potentially have an altered or diminished response to life's natural risk or situations of embarrassment. They are expressions of social issues.

Social issues are understood to be aspects related to manifestations of social inequality and to the political and social aspects that are related to such inequality (Yamamoto \& Oliveira, 2010). The stance adopted by psychology in this context is to make the individual a protagonist, who is understood to be a biopsychosocial being for promoting quality of life and well-being (Alberto et al., 2014; Macêdo, Alberto, \& Pessoa, 2015; Ribeiro \& Guzzo, 2014, Oliveira et al., 2014, and others).

It is not part of the proposal of the basic social protection of the public social welfare policy to provide individual psychotherapeutic consultations, but as an ethical commitment and as a way of establishing links, people may be humanely dealt with and the individual and his/her family may be provided with guidance and refer- ral to the care units that deal with mental health issues, as is the case with the Family Health Support Center (NASF), the Psychosocial Care Center (CAPS), or the therapeutic residences. What psychology professionals do in the face of the demands they face will be addressed in the next section.

\section{Activities Carried Out}

The following categories emerged from the words of the psychology professionals about what they do in a typical working week: home visits / follow-ups, individual care, referrals, and guidance for team members. The empirical data revealed that, in the words of the psychology professionals, activities of a psychosocial nature stand out. Such activities involve either active search, the monitoring of families that live in a situation of social vulnerability, or visits to families, represented by the 'home visits / follow-up' category.

The 'Individual care' category, which emerged from what the psychology professionals from towns surrounding Cajazeiras said, means they listen to, receive, triage and guide individuals. The 'Referral' category reveals that in order to meet the demands of users, CRAS psychology professionals make use of other facilities that come from both the public welfare policy (Specialized Welfare Reference Center - CREAS) and from other policies, particularly the health policy, by way of the Psychosocial Care Centers (CAPS). From the words of the psychology professionals, there also emerged 'Socio-educational activities' category, which reveals actions involving conversation circles, talks, group facilitation and orientation from other professionals who facilitate groups.

Unlike what was identified by other studies (Macêdo, Alberto, Santos et al., 2015), from the words of the psychology professionals who work in the CRAS in the interior of Paraíba, it is noticeable that although individualized care did not emerge as a main activity undertaken by these professionals, it is still present in a representative way in the actions of these professionals.

The empirical data reveal, therefore, on the one hand that the work of psychology profes- 
sionals in the CRAS is becoming very similar to what is prescribed for this work, a fact that was also identified by Flor and Goto (2015) and Oliveira et al. (2011). As Macêdo, Alberto, Santos et al. (2015) and Ribeiro and Guzzo (2014) point out, the role of the psychology professional in the CRAS is to analyze the subjective dimension, seeking to understand how each individual organizes and appropriates the social conditions that surround them and how they experience this reality. In doing so, and with the aim of developing autonomy and social protagonism, they are guided by actions that are based on making social rights effective and committed to social transformation.

On the other hand, the data also reveal that actions based on an individualizing clinical model still play a prominent role in the actions of psychology professionals. The following statement is representative of this: "I use techniques that you could use in a private practice, don't I? Everything in the same way. I've always tried to help [referring to users]" (Interviewee 3, a 45year old, female, who graduated five years ago).

This is not a question of denying the importance of individualized care, but it is important that psychology professionals are clear that such actions must gain contours that are different from the work done in clinical practice, since the purpose of such consultations must be to welcome the user, clarify doubts and enable them to know and get close to the service, since this action is part of the public social welfare policy. The actions of psychology professionals in the CRAS should be guided toward raising the awareness of users, thus provoking in them reflections about their reality and encouraging them to achieve greater dominance over the objective reality with which they interact and over their own actions in the world, by way of an awarenessraising process (Vygotsky, 1934/2007). Strategies must be constructed in an interdisciplinary and intersectoral way for actions that help users perceive themselves as being "part of the social and political occurrences and to envisage possibilities for action in the light of the problems they face" (Ribeiro \& Guzzo, 2014, p. 90). Such actions help users understand they are citizens who have rights (Silva et al., 2011), causing them to reflect, and so allowing them to understand the extent and social dimension of the phenomena known as vulnerability and poverty (Sicari et al., 2015).

In this sense we were struck by the fact that a factor that marked the uniqueness of just one of the psychology professionals who works in the CRAS in the interior of Paraíba was what they said about their participation in CRAS team meetings and the case discussions that are used for planning the activities to be carried out. Questions are, therefore, raised about the scope of these actions with a psychosocial character, since the statements provided no evidence that there was any planning of the activities and actions that seek to make the functioning of the social assistance network effective. This interdisciplinary and intersectoral action will be addressed in the next section.

\section{Working Conditions}

In asking questions about the working conditions offered to the psychology professionals who participated in the study, the empirical data revealed several limitations that make it difficult for them to carry out their work. The following categories emerged from what they said: transportation, a shortage of material and a breakdown in the social assistance network.

The professionals were unanimous in what they said about the 'Transportation' category. They revealed the existence of difficulties related to a lack of exclusive transportation, a driver and fuel for the CRAS facility, which would meet the development needs of their activities, as can be seen in the following statement.

We don't have any transportation in the CRAS. We have just one means of transport for all the welfare services and then there's the difficulty of driver availability. . . we have several obstacles we come up against that make visits difficult. It gets to the point where the social worker has to use their own automobile. (Interviewee 1, a 28-year old, female, who graduated six years ago) 
The 'Scarce material' category, which emerged from the reports of study participants, reveals limits in office material and a lack of recreational material and snacks for users participating in CRAS activities. From what the professionals said, these aspects make it difficult to work in the CRAS, which, added to the low salaries, makes it difficult for the professionals to get more involved in the search for guaranteeing user rights. This was also identified by Macedo and Dimenstein (2012), who found that the structure of the facilities and resources available are minimal when it comes to developing work with the users. They also add issues regarding salary conditions and the workload that often affect the professionals' work. The following statement is representative of how psychology professionals working in the CRAS in the interior of Paraíba perceive this matter.

What was happening was that we were getting down, we were really tired, because in the beginning you have that buzz and excitement to do things, to plan, but however hard you try and insist, there comes a time when you get tired. (Interviewee 1, a 28-year old, female, who graduated six years ago)

These conditions, which are unsuitable for psychology professionals working with the public social welfare policy, were also identified by other studies (Macedo et al., 2015; Oliveira et al., 2014; Romagnoli, 2016; Ribeiro \& Guzzo, and others). As Romagnoli (2016) emphasizes, this reality has a direct repercussion on the actions of the professionals "who are fragile, impoverished and deprived of rights and collective organization" (Romagnoli, 2016, p. 156).

With regard to the 'Breakdown in the social welfare network' category, this denotes failures in intersectoral work. In the words of the psychology professionals, this category brought to light difficulties related to the articulation of the social welfare network, which led to negative consequences both for the work the professionals do and for making user rights effective, since referrals to other facilities of the public social welfare policy or of other public policies is compromised.
This lack of articulation of the network was also identified by other studies (Flor \& Goto, 2015; Macêdo, 2014; Ribeiro \& Guzzo, 2014, and others). As Ribeiro and Guzzo (2014) point out, this problem reveals that the intersectoral principle, guided by the PNAS and Technical References of the CFP, is far from becoming effective. As relevant factors for understanding these functioning conditions of the CRAS, Macêdo (2014) emphasizes both the academic background, which focuses on traditionalism, based on liberal practices, and 'psychologizing' analyses, which are far from the social question and the collective reality of the users of public social welfare policies, and the current context of the intensification of neoliberalism and the consequent dismantling of public policies, which has been making the working conditions of professionals in such a context even more precarious.

These aspects are considered to be fundamental to our understanding of the actions of psychology in the CRAS in the interior of Paraíba. The elements presented by the professionals constitute their conceptions (Vygotski, 1934/2009) and are backed by culture, the professional groups of which they are part, their relationships with others, their academic background, and the relationship of these professionals with the other technicians and managers of these policies, which have repercussions on the performance of these professionals, in the condition of social practice.

The focus of action of psychology professionals and other CRAS professionals should be the living conditions of the people, the structural poverty (Oliveira et al., 2014), in accordance with PNAS guidelines and objectives. They should provide services and programs based on the organization and hierarchization of network actions, interdisciplinary action that is integrated within the local context, thus identifying and boosting psychosocial resources, promoting social participation and controlling this policy. The empirical data, however, show a concrete reality; historical, political and cultural conditions that make it impossible to really consolidate social welfare as a public policy. 


\section{Final Considerations}

From the analysis carried out, the indication is that the actions of psychology professionals in the daily life of the CRAS have made progress, since, in the words of the professionals, by way of psychosocial action they are closer to an action logic that is coherent with what is prescribed for psychology work within the context of the basic social protection of the public social welfare policy. But technologies that derive from a traditional clinical model still exert a significant influence on the actions of these professionals. Another weakness in the actions of CRAS professionals in the interior of Paraíba refers to the very scope of the actions with a psychosocial character that are put into practice, given the limited analysis that is undertaken of the realities of the users and little planning that is done of the interventions to be carried out.

In view of the current situation, which is marked by an increasing dismantling of social policies and precarious working conditions, in order for the psychology professionals to be able to contribute to truly meeting the demands of CRAS users, when dealing with expressions of social issues they need to go beyond introducing isolated, discontinuous and decontextualized actions. If not, psychology will be part of a broad strategy for normalizing the poor population by means of state regulation over life, thus shaping certain forms of subjectivity (Hillesheim \& Cruz, 2012) and thereby serving the interests of the elite and not the CRAS users.

It is the responsibility of psychology professionals, together with the CRAS team: to think of actions that overcome individualizing perspectives that are guided by the mere relief of psychic suffering; to raise awareness and promote protagonism in users; and to focus on people's living conditions and structural poverty, to the detriment of welfarist or repressive practices. Therefore, the psychology professionals who work in the CRAS must be attentive to the tensions between the State and civil society, to the functionality of the CRAS and psychology for maintaining the capitalist mode of produc- tion. This demands continuity in the advances in academic formation in psychology, implementation of the permanent education proposal envisaged in the SUAS and operationalization of the PNAS in accordance with the legal frameworks of this policy.

This is not a question of denying the contribution of psychology, but rather drawing attention to the importance of its contribution for demanding from the State and managers different treatment for public policies, so we can move forward in consolidating a system for guaranteeing rights that effectively manages to promote changes in the distribution patterns of socially produced wealth, and not regress, as has been happening.

It is not intended here to hold psychology professionals or training institutions responsible for the limited reach of psychology actions. But it is considered that the reality of CRAS users, marked by low income, the absence or precariousness of work, and precarious access to basic living conditions, demands a psychosocial approach that is based on a critical analysis and committed to the social transformation of reality, by way of interdisciplinary and intersectoral action, with a clear ethical and political commitment, so that public policies and support networks are effectively constructed.

Analyses of the actions of psychology professionals in the CRAS by way of in loco observations could provide more accurate data about the object of study in question. This is a limitation of the study, as is the fact that it looks at a specific reality and takes into consideration only the perspective of the psychology professional, disregarding the perspective of users and managers of the CRAS regarding this action. It is suggested, therefore, that future research should consider these aspects and adopt other methodologies, in order to check the generalization power of the findings presented in this study.

\section{Authors Contributions}

Substantial contribution in the concept and design of the study: Orlando Macêdo. 
Contribution to data collection: Clarissa Lima, Francisco de Brito. Josefa de Souza, Noélia de Sousa, Samara de Sousa e Stefania Dias.

Contribution to data analysis and interpretation: Orlando Macêdo, Clarissa Lima, Francisco de Brito, Josefa de Souza, Noélia de Sousa, Samara de Sousa e Stefania Dias.

Contribution to manuscript preparation: Orlando Macêdo, Clarissa Lima, Francisco de Brito, Josefa de Souza, Noélia de Sousa, Samara de Sousa e Stefania Dias.

Contribution to critical revision, adding intelectual content: Orlando Macêdo, Josefa de Souza, Noélia de Sousa, Samara de Sousa e Stefania Dias.

\section{Conflicts of interest}

The authors declare that they have no conflict of interest related to the publication of this manuscript.

\section{References}

Alberto, M. F. P., Freire, M. L., Leite, F. M., \& Gouveia, C. N. N. A. (2014). As Políticas Públicas de Assistência Social e a atuação dos(as) psicólogos(as). In I. F. Oliveira \& O. H. Yamamoto (Eds.), Psicologia e Políticas Sociais: Temas em debate (pp. 127-174). Belém, PA: Universidade Federal do Pará.

Bardin, L. (2009). Análise de Conteúdo. Lisboa: Edições 70.

Conselho Federal de Psicologia. (2007). Referência técnica para atuação do(a) psicólogo(a) no CRAS/SUAS. Brasília, DF: Author. Retrieved from http://www.crpsp.org.br/portal/comunicacao/artes-graficas/arquivos/2008-CREPOP-CRAS-SUAS.pdf

Conselho Federal de Psicologia. (2011). Como os Psicólogos e as Psicólogas podem contribuir para avançar o Sistema Único de Assistência Social (SUAS) - Informações para gestoras e gestores. Brasília, DF: Author. Retrieved from http:// crepop.pol.org.br/1286_crepopcfp-documento-para-gestores-da-assistencia-social-suas-2

Conselho Federal de Psicologia. (2013). Referências Técnicas para a Prática de Psicólogas (os) no Centro de Referência Especializado da Assis- tência Social - CREAS. Brasília, DF: Author. Retrieved from http://www.crpsp.org.br/portal/ comunicacao/artes-graficas/arquivos/2013-CREPOP-CREAS.pdf

Conselho Nacional de Educação. (2004). Resolução $n^{\circ} 8$, de 7 de maio de 2004. Institui as diretrizes curriculares nacionais para os cursos de graduação em Psicologia. Brasília, DF: Ministério da Educação.

Constituição da República Federativa do Brasil de 1988. (1988). Brasília, DF: Casa Civil da Presidência da República.

Cruz, L. R., \& Guareshi, N. M. F. (2010). A Constituição da Assistência Social como Política Pública: Interrogações à Psicologia. In L. R. Cruz $\&$ N. M. F. (Eds.), Políticas Públicas e assistência social: Diálogo com as práticas psicológicas (pp. 13-40). Petrópolis, RJ: Vozes.

Flor, T. C., \& Goto, T. A. (2015). Atuação do psicólogo no CRAS: Uma análise fenomenológico-empírica. Revista da Abordagem Gestáltica, 21(1), 22-34. Retrieved from http://pepsic.bvsalud.org/pdf/rag/v21n1/v21n1a04.pdf

Florentino, B. R. B. (2014). Abuso sexual, crianças e adolescentes: Reflexões para o psicólogo que trabalha no CREAS. Fractal: Revista de Psicologia, 26(1), 59-70. Retrieved from http://www. scielo.br/pdf/fractal/v26n1/v26n1a06.pdf

Fontanella, B. J. B., Ricas, J., \& Turato, E. R. (2008). Amostragem por saturação em pesquisa qualitativa. Caderno de Saúde Pública, 24(1),17-27. Retrieved from http://www.scielo.br/pdf/csp/ v24n1/02.pdf

Freire, M. L., \& Alberto, M. F. P. (2013). Centro de referência especializada de assistência social: Suporte organizacional para atuação do psicólogo. Cadernos de Psicologia Social do Trabalho, 16(2), 167-182. Retrieved from http://pepsic.bvsalud.org/pdf/cpst/v16n2/a03v16n2.pdf

Gonçalves, M. G. M. (2010). Psicologia, Subjetividade e Políticas Públicas. São Paulo, SP: Cortez.

Hillesheim, B., \& Cruz, L. R. (2012). Do território às políticas públicas: Governamento, práticas psicológicas e busca ativa no CRAS. In L. R. Cruz \& N. Guareschi (Eds.), O psicólogo e as políticas públicas de assistência social (pp. 91-105). Petrópolis, RJ: Vozes.

Law No. 8,742. (1993). Retrieved from http://www. planalto.gov.br/ccivil_03/leis/L8742.htm. 
Macedo, J. P. M., Sousa, A. P., Carvalho, D. M., Magalhães, M. A., Sousa, F. M. S., \& Dimenstein, M. (2011). O psicólogo brasileiro no SUAS: Quantos somos e onde estamos? Psicologia em Estudo, 16(3), 479-489. doi: 10.1590/S141373722011000300015

Macedo, J. P. S. (2007). O psicólogo no campo de bem-estar: Cartografias de práticas na assistência social e saúde (Master thesis, Universidade Federal do Rio Grande do Norte, Natal, RN, Brazil).

Macedo, J. P., \& Dimenstein, M. (2012). O trabalho dos psicólogos nas políticas sociais no Brasil. Avances en Psicología Latinoamericana, 30(1), 182-192. doi: 10.1590/S141498932013000400005

Macêdo, O. J. V. (2014). Atuação de profissionais de psicologia nas políticas públicas de proteção social no âmbito da assistência social (Doctoral dissertation, Universidade Federal da Paraíba, João Pessoa, PB, Brazil).

Macêdo, O. J. V., Alberto, M. F. P., \& Pessoa, M. C. B. (2015). Atuação dos profissionais de psicologia junto à infância e à adolescência nas políticas públicas de assistência social. Psicologia: Ciência e Profissão, 35(3), 916-931. doi: 10.1590/1982-3703000922014

Macêdo, O. J. V., Alberto, M. F. P., Santos, D. P., Souza, G. P., \& Oliveira, V. S. (2015). Ações do profissional de psicologia no Centro de Referência da Assistência Social. Psicologia: Ciência e Profissão, 35(3), 809-823. doi: 10.1590/19823703001632013

Ministério do Desenvolvimento Social e Combate à Fome. (2009). Tipificação nacional de serviços socioassistenciais. Brasília, DF: Author.

Ministério do Desenvolvimento Social. (2004). Política Nacional de Assistência Social. Sistema Único de Assistência Social - SUAS. Brasília, DF: Author.

Moreira, T. A. S., \& Paiva, I. L. (2015). A atuação do psicólogo nos Serviços de Acolhimento Institucional de crianças e adolescentes. Psicologia em Estudo, 20(3), 507-517. doi: 10.4025/psicolestud.v20i3.27288

Motta, R. F., \& Scarparo, H. B. K. (2013). A Psicologia na assistência social: Transitar, travessia. Psicologia \& Sociedade, 25(1), 230-239. doi: $10.1590 / \mathrm{S} 0102-71822013000100025$
National Health Council, Ministry of Health. (2012, December 12). Resolution 466/12. Diário Oficial da União. Retrieved from http://conselho. saude.gov.br/resolucoes/2012/Reso466.pdf

Oliveira, C. M. C., \& Heckert, A. L. C. (2013). Os Centros de Referência de Assistência Social e as artes de governar. Fractal, 25(1), 145-160. doi: 10.1590/S1984-02922013000100010

Oliveira, I. F., Dantas, C. M. B., Solon, A. F. A. C., \& Amorim, K, M. O. (2011). A prática psicológica na proteção social básica do SUAS [Special issue]. Psicologia \& Sociedade, 23, 140-149. doi: 10.1590/S0102-71822011000400017

Oliveira, I. F., Oliveira, N. L. A., Nascimento, M. N. C., Araújo, R. L., Coelho-Lima, F., \& Amorim, K. M. O. (2014). Atuação dos psicólogos nos CRAS do interior do RN. Psicologia \& Sociedade, 2(26), 103-112. doi: 10.1590/S010271822014000600011

Pereira, V. T., \& Guareshi, P. A. (2016). O CRAS em relação: Profissionais e usuários(as) em movimento. Fractal, 28(1), 102-110. doi: 10.1590/1984-0292/1153

Ribeiro, A. B., Paiva, I. L., Seixas, P. S., \& Oliveira, I. M. F. F. (2014). Desafios da atuação dos psicólogos nos CREAS do Rio Grande do Norte. Fractal: Revista de Psicologia, 26(2), 461-478. Retrieved from http://www.scielo.br/pdf/fractal/ v26n2/1984-0292-fractal-26-02-00461.pdf

Ribeiro, M. E., \& Guzzo, R. S. L. (2014). Psicologia no Sistema Único de Assistência Social (SUAS): Reflexões críticas sobre ações e dilemas profissionais. Pesquisas e Práticas Psicossociais, 9(1), 83-96. Retrieved from http://www. seer.ufsj.edu.br/index.php/revista_ppp/article/ viewFile/837/651

Romagnoli, R. C. (2015). Problematizando as noções de vulnerabilidade e risco social no cotidiano do SUAS. Psicologia em Estudo, 20(3), 449-459. doi: $10.4025 /$ psicolestud.v20i3.28707

Romagnoli, R. C. (2016). Relações macropolíticas e micropolíticas no cotidiano da equipe profissional do Centro de Referência em Assistência Social - CRAS. Psicologia e Sociedade, 28(1), 151161. doi: 10.1590/1807-03102015v28n1p151

Russo, G., Cisne, M., \& Bretas, T. (2008). Questão social e mediação de gênero: A marca feminina na assistência social. Ser Social, 10(22). Retrieved from www.periodicos.unb.br/index.php/ SER_Social/article/download/20/17 
Seixas, P. S., Coelho-Lima, F., Fernandes, S. R. F., Andrade, L. R. M., \& Yamamoto, O. H. (2016). As políticas sociais nos fundamentos dos projetos pedagógicos dos cursos de Psicologia. Psicologia Escolar e Educacional, 20(3), 437446. doi: 10.1590/2175-3539/2015/02031005

Senra, C. M. G., \& Guzzo, R. S. L. (2012). Assistência social e psicologia: Sobre tensões e conflitos do psicólogo no cotidiano do serviço público. Psicologia \& Sociedade, 24(2), 293-299. Retrieved from http://www.scielo.br/pdf/psoc/ v24n2/05.pdf

Sicari, A. A., Oliveira, T. R. de, \& Pereira, E. R. (2015). Grupos de discussão no CRAS: Problematizando a pobreza e seus desdobramentos. Revista da SPAGESP, 16(2), 88-101. Retrieved from http://pepsic.bvsalud.org/pdf/rspagesp/ v16n2/v16n2a08.pdf

Silva, C. S., Silva, I. R., Brustolin, M. L., \& Pessini, M. A. (2011). Algumas considerações sobre as influências do assistencialismo nas práticas psicológicas realizadas nos Centros de Referência de Assistência Social (CRAS). Akrópolis Umuarama, 19(1), 3-13. Retrieved from www. revistas.unipar.br/index.php/akropolis/article/ download/3474/2336

Siqueira, K. de O. M., \& Lino, M. V. (2013). Assistência Social e Biopoder: Produzindo "vulnerabilidades", prevenindo "riscos" e normalizando as formas de viver. Mnemosine, 9(2), 35-53. doi: 10.4025/psicolestud.v20i3.28707
Vygotski, L. S. (2007). A formação social da mente: $O$ desenvolvimento dos processos superiores ( $\mathrm{P}$. Bezerra, Trans.). São Paulo, SP: WMF Martins Fontes. (Original work published 1934)

Vygotski, L. S. (2009). A construção do pensamento e da linguagem (P. Bezerra, Trans.). São Paulo, SP: WMF Martins Fontes. (Original work published 1934)

Ximenes, V. M., De Paula, L. R. C., \& Barros, J. P. P. (2009). Psicologia Comunitária e Política de Assistência Social: Diálogos sobre atuações em comunidades. Psicologia Ciência e Profissão, 29 (4), 686-699. doi: 10.1590/S141498932009000400004

Yamamoto, O. H., \& Oliveira, I. F. (2010). Política social e psicologia: Uma trajetória de 25 anos. Psicologia: Teoria e Pesquisa, 26(26), 9-24. doi: 10.1590/S0102-37722010000500002

(c) BY 1 (C) The Author(s), 2018. Open Access. This article is distributed under the terms of the Creative Commons Attribution 4.0 International License (http://creativecommons.org/licenses/by/4.0/), which permits unrestricted use, distribution, and reproduction in any medium, provided you give appropriate credit to the original author(s) and the source, provide a link to the Creative Commons license, and indicate if changes were made. 